\title{
Preliminary results of the Yodhawewa Archaeological Research in Sri Lanka - 2018: Exploration, Excavations, Findings, and Radiocarbon Datings
}

\author{
Wijepala, WMTB ${ }^{1,2}$., Young, SM. ${ }^{3}$., Ishiga, H. ${ }^{1}$ \\ ${ }^{1 .}$ Department of Earth Science, Interdisciplinary Faculty of Science and Engineering, Shimane University, 1060, \\ Shimane 690-8504, Japan. \\ 2. Department of Archaeology and Heritage Management, Faculty of Social Sciences and Humanities, Rajarata \\ University of Sri Lanka, Mihintale, Sri Lanka. \\ 3. Department of Environmental Technology, Faculty of Technology, University of Colombo, Sri Lanka.
} tbwijepala@ssh.rjt.ac.lk

\begin{abstract}
This archaeological research aimed to investigate the authentic metalworking activities of the Yodhawewa area and examine contemporary socio-economic movements based on discovered material culture. The entire research work was carried out in 2018 based on a surface survey and two excavations in an area of about $201600 \mathrm{~m}^{2}$ on the outskirts of Yodhawewa reservoir. The C14 chronology confirms the $1^{\text {st }}-8^{\text {th }}$ centuries activities, and in this research obtained a considerable artefacts collection related to metal extraction, copper metalwork, and crucible steel production. This research also discovered that half of a lower spherical (crucible-typed) metal furnace was used to produce crucible steel for the first time in Sri Lanka. Artefacts such as coins, BRW, RW, and some porcelain prove that the site maintained cultural relations with India and China in the c. $1^{\text {st }}$ century and $8^{\text {th }}$ century AD. Other artefacts of this site include ceramics, beads, faunal remains, minerals, and rocks that have been used for human needs for a considerable period. This article discusses at length the archaeological evidence that the Yodhawewa region is a metalworking site that has been active since the early historical period of Sri Lanka and a place that reflects national and international cultural relations.
\end{abstract}

Keywords: Copper, Crucibles, furnace, Metal Slags, Yodhawewa 


\section{Introduction}

There is a copious amount of literature produced by the researchers who have focused on the South Indian Ocean port city of Mannar or 'Mantai' as known and its archaeological value. The book "Mantai: City by the Sea" provides an extensive description of archaeological research centred on the port city of Mannar at various times since the 1880s (Carswell et al., 2013). Through such studies, it was shown that the Mantai ancient port in north-western Sri Lanka was one of the major ports in the route of East and West trade in the Indian Ocean. The archaeological record of the Mantai shows its wide range and diversified links with the local and international trade networks (Bohingamuwa, 2017; Prickett-Fernando, 2003). As the port-city of Mannar became an important economic centre in South Asia, researchers did not pay much attention to how it affected settlements in the surrounding suburbs.

Significant research has been done in ancient Sri Lanka in various fields such as regional metalwork, metal artefacts, raw materials for metal production, and technological parameters related to metalworking (Juleff, 1996, 2015; Seneviratne, 1985, 1995; Solangaraarachchi, 2011). The oldest evidence of metallurgical activities found at Anuradhapura citadel (c. 834-778 BC), Sigiriya-Aligala excavation, and the Pomparippu megalithic burial excavation (c. 998-848 BC) in Sri Lanka (Begley et al., 1981; Deraniyagala, 1992; Karunaratne \& Adikari, 1994). They mainly focused on local iron smelting, iron production, and copper metallurgy. Then, two research related to two types of metal furnaces in ancient Sri Lanka stands out; (a) Samanalawewa research based on the seasonal monsoon wind power through the west-facing furnace technology in the $5^{\text {th }}$ century $\mathrm{BC}$ to $12^{\text {th }}$ century AD (Juleff, 1996), and (b) The magnetite iron ore extraction furnaces in the Sigiriya (Kiri Oya Basin - KOB) with the evidence of c. $3^{\text {rd }}$ century BC to $10^{\text {th }}$ century AD (Solangaraarachchi, 2011). Thantilage and Vithanage (2015) have also conducted significant research, including primary metal ore deposits, ancient smelting, and metal production sites, and some iron ore geochemical descriptions in Sri Lanka. 
Furthermore, Seneviratne's studies (1995) on the quantitative factors, utility, and consumption of the Seruvila copper deposit near Trincomalee (East province in Sri Lanka) are particularly significant. Some researchers have explained that the utility of the Seruvila copper deposit was also crucial in coinciding with the demand for copper in South India (Juleff, 2013; Seneviratne, 1995; Srinivasan, 2016).

Ancient crucible steel production is a technological transformation of iron production in the world. The Kodumanal site in Tamil Nadu has uncovered a small circular furnace cluster (more than 12 furnaces) used for the production of crucible steel/wootz, and the earliest evidence (300 BC) of semi-solid crucible steel (Gullapalli 2009; Sasisekaran \& Raghunatha Rao, 2001; Sasisekaran 2002; Srinivasan, 2013, 1997; Srinivasan \& Ranganathan, 2004). Archaeological evidence for this type of circular (crucible-shaped) furnaces was not reported until the Yodhawewa was discovered. Ondaatje (1854) and Coomaraswamy (1908/1962) have provided eyewitness accounts of Sri Lankan crucible-steel production in recent history (Juleff 1996; Solangaraarachchi 2011), and most recently, a significant intervention has been carried out by Juleff (1996). Arab writers such as Al-Kindi report a tremendous demand for Sri Lankan (Sarandibi) steel from the Islamic world in the $6^{\text {th }}-9^{\text {th }}$ centuries AD (Juleff 1996). Analyzing the metal facts of Mannar (excavations 1980-84), Juleff (2013) pointed out that high-quality steel produced in Sarandibi may have been exported through the Mannar port.

Due to the central location on the South Asian silk road and the extensive port system around the country, Sri Lanka has maintained an excellent cultural network globally in ancient times (Carswell et al., 2013; Weisshaar, Roth, et al., 2001). Foreign artefacts such as pottery, coins, beads can form a broad discourse on cultural relations not recorded in the written literature. The quantities of foreign artefacts discovered in Sri Lanka help provide a quantitative and qualitative interpretation of these relationships. Here we intend to comment on some of such specific artefacts discovered by the Yodhawewa research. 
The adverse effects of the civil war in the Northern and Eastern Provinces of Sri Lanka during 1983-2009 also significantly changed the geo-environmental conditions of the region, and archaeological sites were accidentally opened due to rapid irrigation projects initiated after 2009. The Yodhawewa archaeological site was discovered in October 2017 during a reconnaissance survey of ancient settlements around the Yodhawewa Reservoir (Giant's Tank). The Department of Archaeology and Heritage Management of the Rajarata University of Sri Lanka conducted a field investigation in 2018 with the Director-General of Archaeology's approval to further observe the material culture and settlements of the Yodhawewa area. This study aimed to provide a chronological description of the movements of the ancient settlement based on the material culture revealed by the archaeological observations. It will provide essential clues as to the impact of commercial activities centred on the port city of Mannar on the settlements in the periphery zone. Two specific objectives were expected to be achieved in this research: (a) Giving a chronological definition to the newly discovered Yodhawewa metalworking activities, and (b) Explaining the authentic technical parameters and resource utilization of the Yodhawewa area through the research findings of 2018.

\section{(I) Study Area and the Geophysical environment of the region}

The archaeological study was conducted near the Yodhawewa reservoir, located 12 $\mathrm{km}$ southeast of the Mannar ancient port city (Fig. 1) and in the 'Yodhawewa' village in the Mannar District North-Western coast and the Northern Province of Sri Lanka. The study area was bounded by the Yodhawewa Sanctuary - east, the Yodhawewa reservoir - South, and the canal and agricultural lands from the north and west. Archaeological investigations of the whole area were carried out beginning from the outer spill of the Yodhawewa reservoir to a length of $1600 \mathrm{~m}$ area, especially on the right bank of the canal in the GPS location 08 $89^{\prime} 14.0^{\prime} \mathrm{N}$ 08004'82.2' E (Fig. 1). 


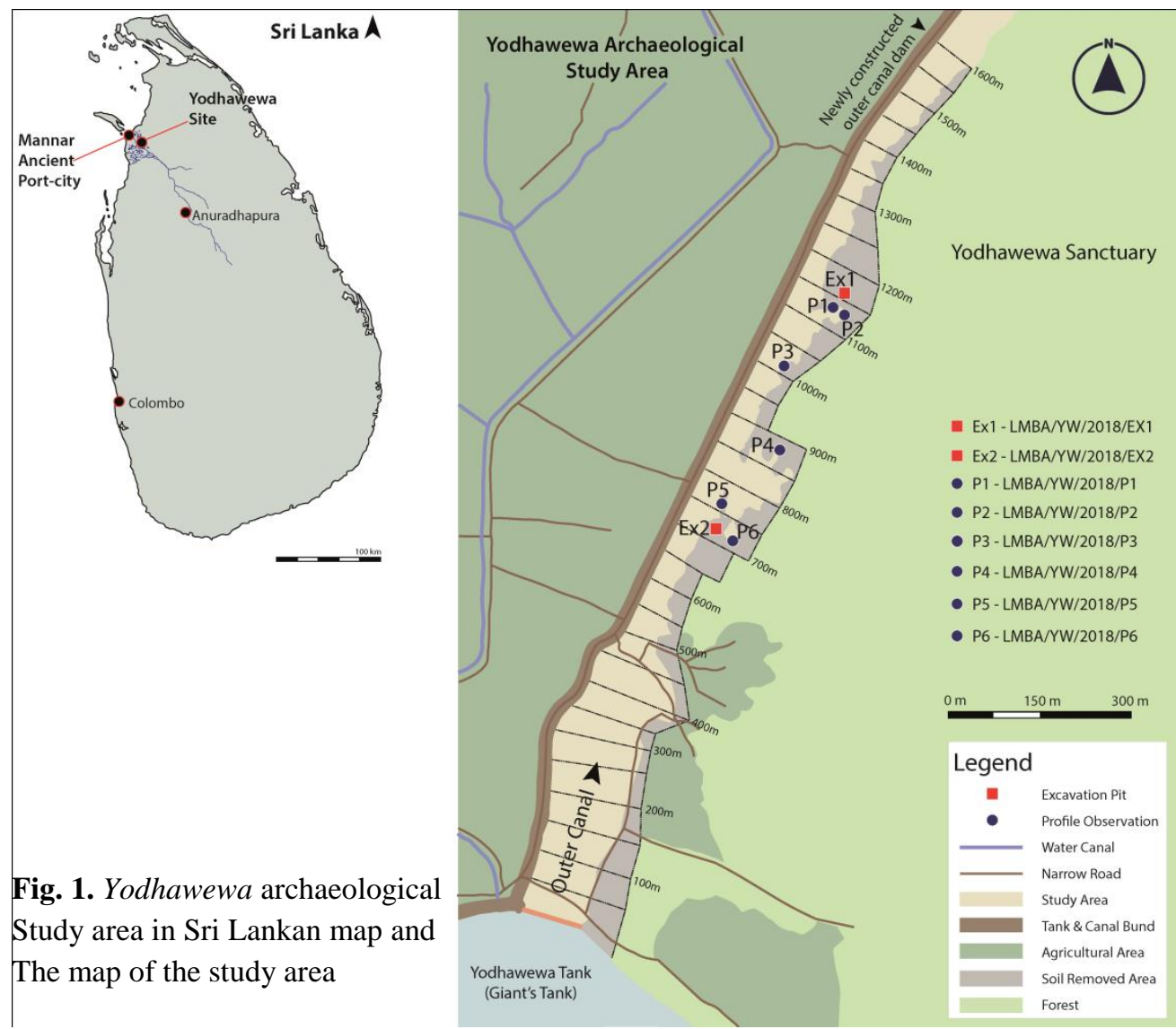

The study area was located in the North-Western plains of Sri Lanka, geologically on the Miocene limestone layer (Cooray \& Katupotha, 1991). The region consists of three soil distributions. The undulating terrain spreads eastward from the Yodhawewa, comprising Reddish Brown Earth developed on the Red Yellow Latosol horizon. The flat coastal terrain mainly comprises alluvial soils, and eroded surfaces and grumusols noticed within the region (Alwis \& Panabokke, 1972). Deposition of alluvial soil was reported from the river and flood basins. Climatically it falls into the North-Western Dry - semi-arid zone and, Grasslands, shrubs with thorny bushes are prominent as vegetation. Despite the prolonged drought, the region receives $<1,200 \mathrm{~mm}$ of rainfall annually, from June to August. The temperature remains high throughout the year causing higher evaporation and relatively low humidity. Droughts after August create a significant impact on the 
soil and the vegetation. The dehydrating South-West monsoon winds prevail from April to August. Dry climatic conditions are frequent; however, floods are reported occasionally (Pemadasa, 1984).

\section{Materials and methods}

\section{a) Surface Sampling}

The exposed surfaces with artefacts were identified during the preliminary site visit at the end of 2017. A formal surface sampling was done through a water canal area of $201600 \mathrm{~m}^{2}$ extended, and it was divided into 32 sampling units in an interval of $50 \mathrm{~m}$. In order to present a detailed and unbiased image of the premise's cultural and natural phenomena, artefacts scattered on the surface were collected to represent each sample unit following the Exploration Procedures (2015) declared by the Department of Archaeology Sri Lanka. Artefacts (pottery, Slags, furnace wall fragments, crucible fragments, beads, shells, coins) were collected and recorded by each sampling unit and were bagged in separate ziplock polythene bags. During the initial observation, several irregular vertical soil profile units were observed in the centre of the study area. Formal profiles $(100 \mathrm{~cm} / 150 \mathrm{~cm} \times 15 \mathrm{~cm})$ of such sites were observed to uncover further information in the study area. Profiles detail were also included in this research under exploration.

\section{b) Excavations}

In selecting the site for the first excavation LMBA/YW/2018/01 (Ex-01) of the Yodhawewa research (Fig. 1, 2a), the geophysical factors, minimal human impact, and the surface artefacts distribution density were considered. The primary purpose of that excavation was to identify the layer distribution pattern of the site and, the minimum to a maximum of $0.50 \mathrm{~m}$ to $0.80 \mathrm{~m}$ depth from the surface level was excavated in the $9 \mathrm{~m}^{2}$ area. The site for the second excavation, LMBA/YW/2018/02 (Ex-02), was selected based on the surface factors of the furnace structure discovered 700-750m sampling unit during the survey (Fig. 1, 2b). The Ex-02 was 
carried out aiming at uncovering information on the technical parameters based on the furnace. The excavation was completed at the end of $0.60 \mathrm{~m}$ to $0.75 \mathrm{~m}$ depth from the surface level. The excavation process followed the established procedure (Standing Order No. 488) of the Department of Archaeology Sri Lanka and included detailed statements, illustrations, measurements, and photographs in contextual reporting.

\section{c) Radiocarbon Datings}

Five charcoal samples were collected from the Ex-02 excavation and dated using Accelerator Mass Spectrometry (AMS) from the Beta Analytic laboratory, USA. All radiocarbon dates were conventional Radiocarbon Ages, and sigmas are rounded to the nearest ten years as for the 1977 International Radiocarbon Conference conventions. When counting statistics when sigmas are lower than \pm 30 years, a conservative $\pm 30 \mathrm{BP}$ was cited for the result. For Beta Analytic, the reported results are accredited to ISO/IEC 17025:2005 testing accreditation PJLA \#59423 standards.

\section{Results and Discussion:}

\section{a) Stratification and Chronology}

The six profiles reported in the surface survey revealed the study area's topography, confirmed that the entire region consisted of five main soil layers. All soil layers in the premises were certainly presented only in Ex-01, P1, and P2 areas and did not signify the same topography in other areas. The exposed facies' recorded depths vary between $120 \mathrm{~cm}-240 \mathrm{~cm}$. The Reddish Brown Earth was developed on the surface level or at 1-40 cm of depth whole study area. The lower horizons comprise reddish-brown soil (Dull Reddish Brown Layer). 

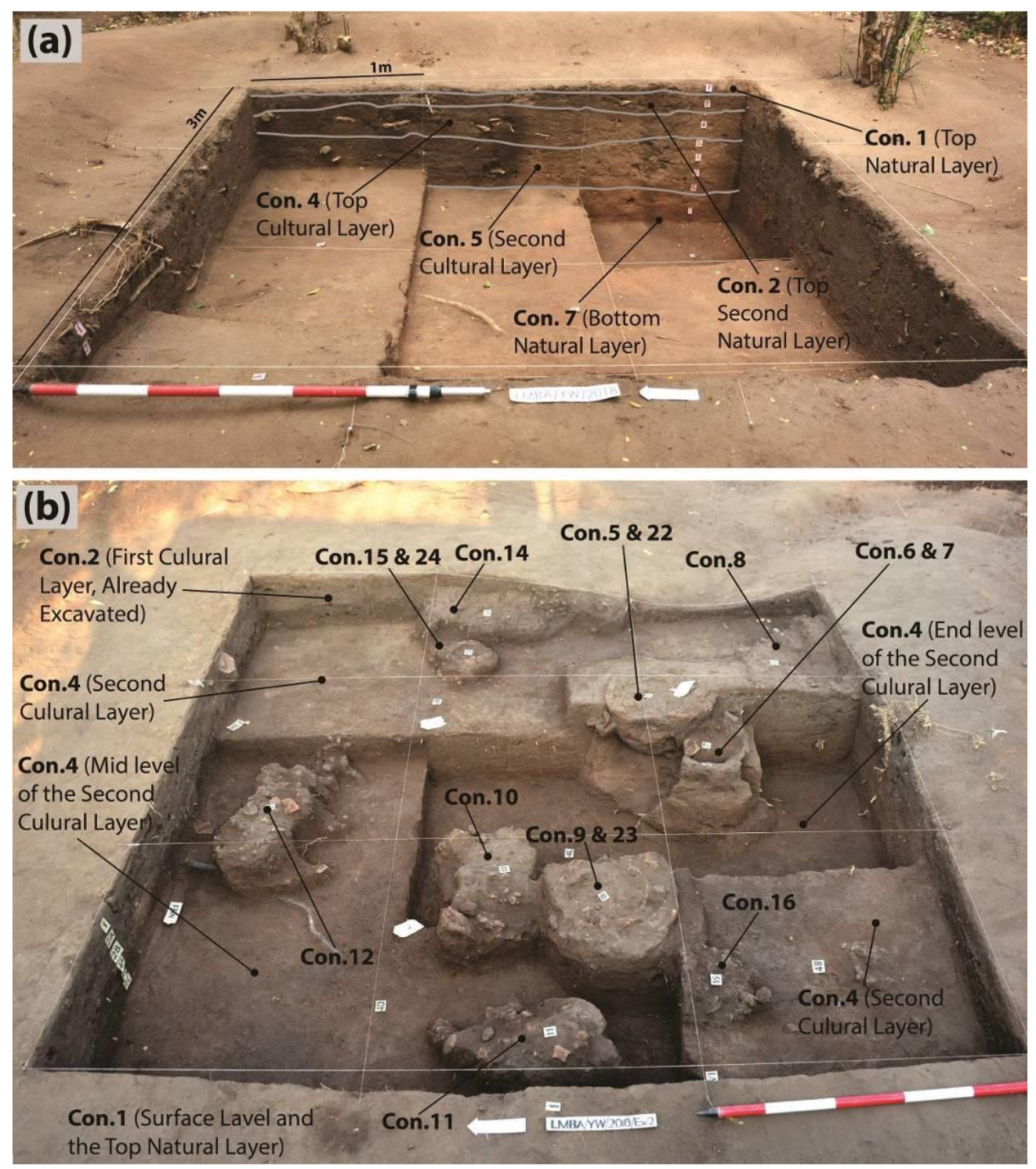

Fig. 2. Two Archaeological excavations in the Yodhawewa site (2018) including specific contexts (a) First excavation pit (LMBA/YW/2018/01) and (b) Second excavation pit (LMBA/YW/2018/02) (Both Photo direction is west to east)

The anthropogenic provenances were noticed from two layers deposited between the upper (one or two) natural layer and characterized only in the Reddish Brown Earth. The Dull Reddish Brown soils in the lower horizon are devoid of any trace of anthropogenic evidence. The lowest horizon of all recorded profiles is a natural 
deposit extending further beneath the exposed area. Based on that data, no attempt has been made to excavate the two main excavations beyond that level.

\begin{tabular}{|c|c|c|c|c|c|c|c|c|c|c|}
\hline Area & Slags & $\begin{array}{c}\text { Crucible } \\
\text { Frag. }\end{array}$ & $\begin{array}{c}\text { Furnace } \\
\text { wall parts }\end{array}$ & $\begin{array}{l}\text { Metal } \\
\text { Frag. }\end{array}$ & Ceramics & Beads & $\begin{array}{l}\text { Glass } \\
\text { Frag. }\end{array}$ & $\begin{array}{c}\text { Rocks/ } \\
\text { Minerals }\end{array}$ & $\begin{array}{l}\text { Flora/ } \\
\text { Fauna }\end{array}$ & Total \\
\hline Ex-01 & 32 & 26 & 1 & 27 & 2110 & 66 & - & - & 1 & 2263 \\
\hline Ex-02 & 6226 & 326 & 193 & 32 & 1217 & 18 & 5 & - & 1 & 8018 \\
\hline Survey & 368 & 63 & 10 & 12 & 1634 & 70 & 30 & 73 & 18 & 2278 \\
\hline P.01 & 77 & 6 & - & - & 5 & - & - & - & - & 88 \\
\hline P.02 & 51 & 59 & 31 & - & 630 & - & - & - & - & 771 \\
\hline P.03 & 2 & - & 2 & - & 34 & - & - & - & - & 38 \\
\hline P.04 & - & - & - & - & 2 & - & - & - & - & 2 \\
\hline P.05 & 17 & - & - & - & 0 & - & - & - & - & 17 \\
\hline P.06 & 41 & - & 14 & - & 481 & 6 & - & - & - & 542 \\
\hline Total & 6814 & 480 & 251 & 71 & 6113 & 160 & 35 & 73 & 20 & 14017 \\
\hline
\end{tabular}

Table 1. Artefacts density of the entire Yodhawewa research in 2018

(a)

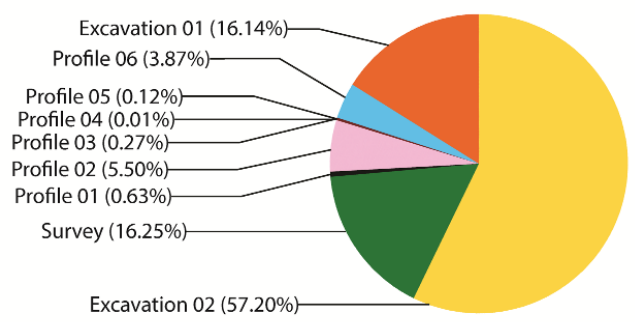

(b)

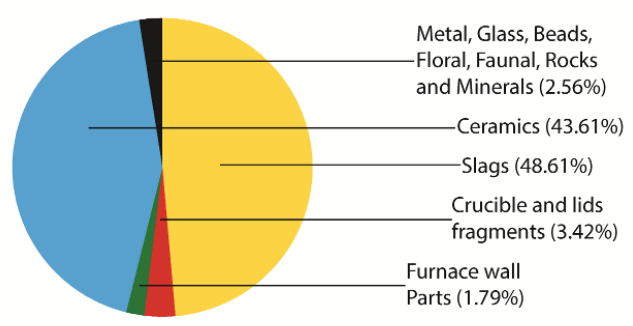

Fig. 3 Artefacts density of the Yodhawewa research in 2018 (a) Location-based percentage and (b) Artefacts type based percentage

The first excavation (Ex-01) reported five main layers and seven contexts. The stratigraphic composition is similar to the profiles registered during the exploration, where two anthropogenic layers $\left(3^{\text {rd }}\right.$ and $4^{\text {th }}$ layers) were sandwiched between the top and bottom natural layers. Several artefacts were reported from the top two layers of this premises and possibly mixed from the lower cultural deposit. Contexts 
1, 2, 4, 5, 7 were the main soil layers in this area, and contexts 3 and 6 could be identified as two sub-soil layers. Accordingly, two natural layers (Contexts 1 and 2) of the surface could be identified, followed by two cultural layers (Contexts 4 and 5). The second culture layer was slightly wider (22-28 cm in height), followed by the natural layer (context 7). As mentioned above, after observing profiles 1 and 2, it was decided to stop probing beyond context 7 (Fig. 2a).

The second excavation (Ex-02) reported 24 contexts in four main layers, and the layers were assigned the numbers, which are the contexts numbers of 1, 2, 4, and 21. The top layer (context 1) is heavily disturbed through the recent canal expansion constructions and secondly by the monsoonal runoff. The second context was the first cultural layer of the premises, and the $4^{\text {th }}$ context was the second cultural layer. Two circular furnace structures (fragmented) were exposed during the excavation and numbered as context 5 and 9. Layers 2 and 4 were the main cultural layers, including the furnace preparation remains, operational debris accumulation, postproduction abandonment, and human-induced debris from later settlement phases. However, contexts 3 and 13 were the sub-soil layers that were not spread over the excavated area. It was decided to stop Ex-02 with the beginning of the bottom natural layer (context 21) based on prior understanding of the Ex-01 and the profiles. Contexts 8, 10, 11, 12, 14, 16, 17, 19, and 20 consisted of ceramics, slags, crucible fragments, and furnace wall fragments. Context 15 was an overturned pottery, and context 18 was an assemblage of potsherds. The contexts 7, 22, 23, 24 were fillings of the contexts 6,5,9, and 15, respectively (Fig. 2b). All the reported profiles and excavations revealed that the region's stratigraphic distribution is almost evenly deposited and has similar attributes, except that the thickness of the layers varies to some extent. Table 1 and Figure 3 show the density of the artefacts discovered from the entire Yodhawewa site.

In preparing a contextual note chronologically, it is essential to inquire about the context in which the samples were acquired. Five charcoal samples were dated from three different contexts; the S-159 sample from an accumulation dated back to the c. 
$1^{\text {st }}$ century AD. Sample S-27 was collected near the main furnace, and results have been confirmed to belong to the c. $5^{\text {th }}$ century AD. The samples of S-48, S-64, and S-78 were collected from the bottom of the fourth context belonging to the c. 8th century AD. Overall, the Yodhawewa site was confirmed by $60 \%$ of $\mathrm{C} 14$ datings as a c. 8th-century $\mathrm{AD}$ site. However, it cannot be ignored that the premises were still activated in the c. $1^{\text {st }}$ and $5^{\text {th }}$ centuries AD (Table 2).

\begin{tabular}{|c|c|c|c|c|c|c|c|}
\hline \multirow{2}{*}{$\begin{array}{c}\text { Sample } \\
\text { Reference } \\
\text { No. }\end{array}$} & \multirow{2}{*}{$\begin{array}{l}\text { Sample Ref. } \\
\text { (Beta analytic } \\
\text { laboratory) }\end{array}$} & \multicolumn{3}{|c|}{ Locality } & \multicolumn{2}{|c|}{ Radiocarbon age } & \multirow[t]{2}{*}{$\begin{array}{c}\text { Accurac } \\
\mathrm{y} \\
\end{array}$} \\
\hline & & Context & $\operatorname{MSL}(\mathrm{m})$ & Location type & cal AD & cal BP & \\
\hline S-159 & Beta -517842 & 12 & 11.45 & Accumlation & $70 \pm 30$ & $1880 \pm 30$ & $95.40 \%$ \\
\hline S-27 & Beta -517342 & 4 & 11.61 & Layer & $430 \pm 30$ & $1520 \pm 30$ & $95.40 \%$ \\
\hline $\mathrm{S}-48$ & Beta -517843 & 4 & 11.41 & Layer & $760 \pm 30$ & $1190 \pm 30$ & $95.40 \%$ \\
\hline S-64 & Beta -517844 & 4 & 11.36 & Layer & $730 \pm 30$ & $1220 \pm 30$ & $95.40 \%$ \\
\hline S-78 & Beta -517343 & 4 & 11.32 & Layer & $730 \pm 30$ & $1220 \pm 30$ & $95.40 \%$ \\
\hline
\end{tabular}

Table 2. Conventional radiocarbon dating of selected contexts of the Excavation no. 2, Yodhawewa Archaeological Research in 2018

\section{b) Metal Extraction evidence of the Yodhawewa site}

Archaeological studies have uncovered much important information about metalworking in the Yodhawewa area. Slags, crucible fragments, metal fragments, and furnace wall fragments are the main material factors in the focus on metalworking in this site. It is noteworthy that the slag was found in both the high weight (metal type) and low weight (glass type). The exploration collected three hundred sixty-eight slags from the surface, and the Ex-01 produced fewer $(n=32)$ slags (Table 1). A large number of slags $(n=6226)$ were recovered from the Ex-02 premises (Table 1); in particular, the context of $8,10,11,12,14$, and 16 shows the highest density. Slags were collected $48.61 \%$ of the total artefact density of the Yodhawewa research (Fig. 3b). 

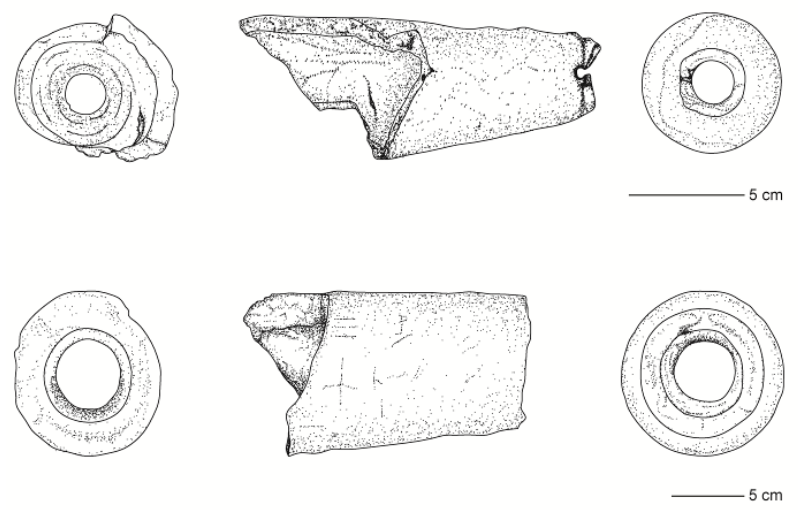

Fig. 4. Different types of two 'Tuyere' fragments were collected from the Yodhawewa survey 2018 (Drawn by N.R. Lankapriya)

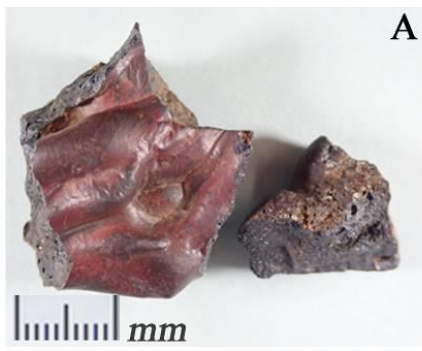

A

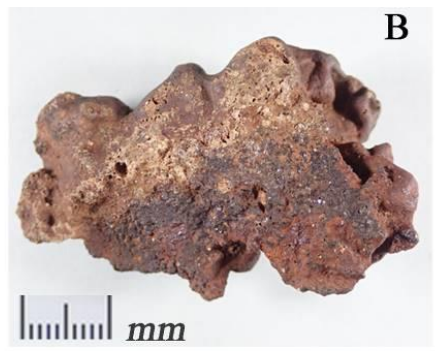

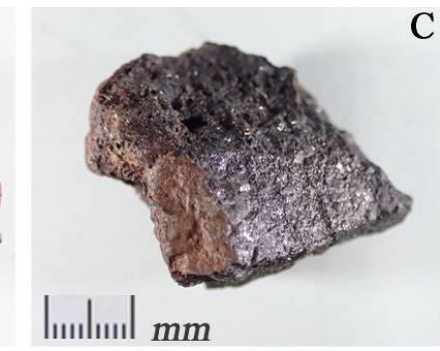
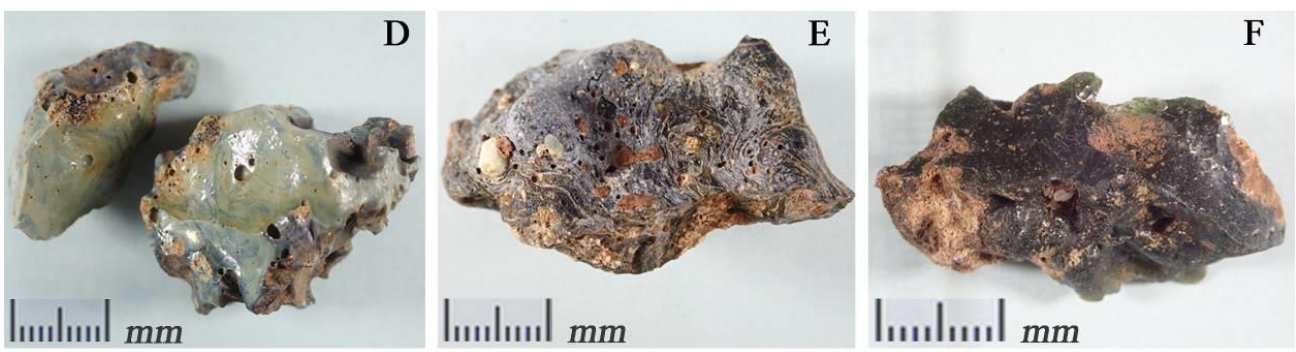

Fig. 5. Slags collected from Yodhawewa site (A) Tap slag (B, C) Metal typed oxidized slags (D, E) Low weight Glass or Glassy typed slags with blue, green, and white-coloured bands, (F) Transparent or translucent green glass slags

Excavations in the Samanalawewa, Matale, and Sigiriya areas of Sri Lanka have uncovered essential facts about iron smelting furnaces (Juleff, 1996, 2013, 2015; Solangaraarachchi, 2011). Two fragments of unvitrified air supplying tuyeres (into metal extraction furnaces) were discovered from the Yodhawewa exploration (Fig. 4). Tap-slag fragments, usually black, red, or reddish-brown, have also been 
acquired from this research (Fig. 5A). The Colour of the slag functions in the 'metallurgical chain,' and the chemical composition usually hinders using slags to identify the initial metallurgical processes (Killick, 2014). Typical tap slags with their unique visual appearance are the best indicators for identifying the iron smelting locations (Eliyahu-Behar et al., 2013). The tap slags are recognized from the ropey texture on their upper surfaces, indicating they cooled from molten, flowing slag, most probably out of the furnace (Georgakopoulou, 2014). The oxidization process can be noticed on some slag surfaces (Fig. 5B-C). The metallic slag collection could be identified as having both high and low weight. Slags were largely discarded with the smelting process (Ettler et al., 2015), and they also usually act as an indicator of the amount of metal extracted. In total, 251 furnace wall fragments $(1.79 \%$ of total artefacts) were discovered during the Yodhawewa research, and they are also more likely to have wall fragments of metal extraction furnaces. The 'Tuyere' fragments, furnace wall fragments, and the large-scale slags collection (including tap slag) were confirmed that the metal extraction took place at this site; however, the complete or fragmented smelting (metal ore) furnace structure could not be identified from the research area in 2018.

\section{c) Crucible Steel Production and the copper metalworking}

Two factors presented clues concerning crucible steel production at the Yodhawewa metalworking site; $(a)$ A lower half of a crucible-shaped furnace and $(b)$ a collection of crucibles and lid fragments. Thus, the most significant discovery of the research was a lower half-spherical (crucible) typed furnace half from the Ex-02 premises. The furnace (context 5) remains the lower spherical part, and the upper part is not visible (Fig. 2B). The remaining half of the inner furnace chamber could show a soil fill (context 22) with the depth of $29 \mathrm{~cm}$, and in the region between 16-22 cm indepth $(11.59 \mathrm{~m}$ to $11.53 \mathrm{~m}$ MSL), 18 pieces of crucible fragments $(>2 \mathrm{~cm})$ were detected. Observing how these crucible fragments existed as a cluster can be referred to as disposal to the furnace chamber by human intervention after the manufacturing process. Because debris of the furnace chamber (context 22) were 
existed with crucible fragments $(n=32)$, slags $(n=8)$, ceramic fragments $(n=3)$, furnace wall part $(n=1)$, a metal fragment $(n=1)$, and a fragment of a clay pipe $(n=1)$ without interconnections. When considering the furnace structure, the wall shows the burned clay pieces, which nicely fit with the clay mortar into the wall to get the circular shape (Fig. 6 top). The wall thickness was 8-12 cm, and there was a bonded inner white colour plaster $1-1.5 \mathrm{~cm}$ thick. It was also noticed that plaster (daub), which was weakened during prolonged use of the same furnace, was maintained by re-coating (Fig. 6 bottom). Such layers often act as thermal insulation coats (Parr \& Boyd, 2002; Weisshaar, Schenk, et al., 2001). There was no 'tuyere' evidence related to the furnace, and In-out connected small "Tube hole" $(\varnothing=2.5 \mathrm{~cm})$ through the furnace wall (west side) could be identified $16 \mathrm{~cm}$ top to the furnace chamber base. Based on the lack of evidence of "tuyere" and the discovery of a small fragment of a clay pipe from the furnace filling (context 22), it can be assumed that the furnace was activated through the "bellow" method.

In this research, the Yodhawewa premises discovered a spherical metal furnace's lower half for the first time in Sri Lanka. Such crucible-shaped steel furnaces were discovered in the Kodumanal megalithic burial excavations (1986-1996) of South India, and they are believed to have been made to make crucible steel (Gullapalli, 2009; Sasisekaran \& Raghunatha Rao, 2001).

These crucible fragments (crucibles and lids) were represented 3.42\% ( $n=480)$ of the entire artefacts of the research, and the majority $(n=326)$ were collected from Ex-02 (Table 1). However, a non-damaged (complete) crucible could not be found, and they have been uncovered as fragments of the rim, body, base, and lids (Fig. 7). The crucibles of Ex-2 represented an elongated tube-shaped and rounded base with an inner diameter of approximately $4 \mathrm{~cm}-6.5 \mathrm{~cm}$. Morphologically, the outer surface was completely dark green or blue (or mixed) with glazy vitrification or a waxy solution. The inner middle or lower part shows glass fins as a smelting line, and the bottom of that line shows a honeycomb pattern. The crucible lids in the Ex-02 area have a unique shape with a small hole connecting the inside and outside of them 
(Fig. 7). Such small holes help balance the heat inside the crucible and expel the gas (Juleff, 1996). Traces of small metal particles were visible inside the crucible's upper parts and the lids. However, there were not found both types of crucibles in the same locations. Compared to Juleff's Samanalawewa (1996) and Hattota Amune (2015) records, the crucibles found in the Yodhawewa Ex-02 were also used to make crucible steel.

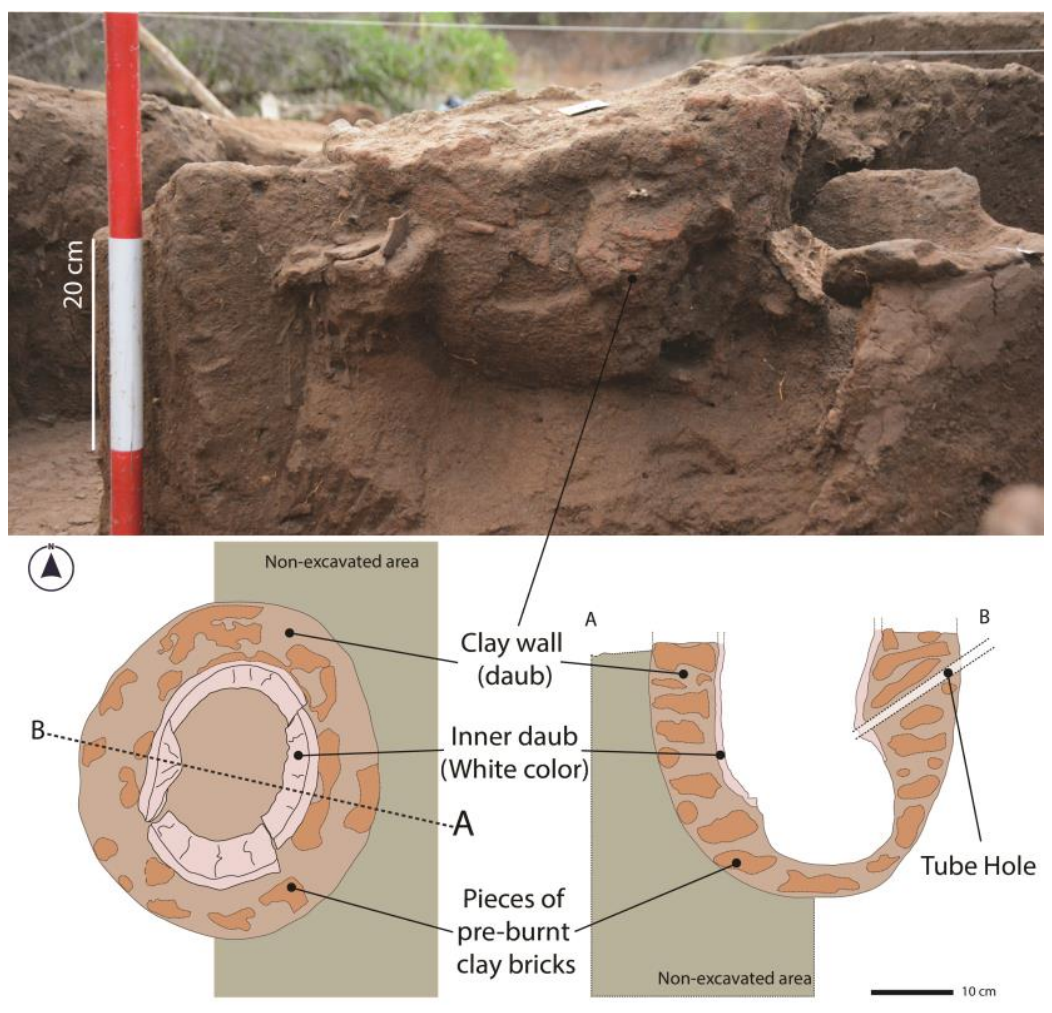

Fig. 6. The crucible-typed furnace (context 5) was discovered from the Yodhawewa site. Outer west face of the furnace (top), detailed plan of the remained furnace top (bottom left), and Cross-sectional details A-B (bottom)

The crucibles' shape, size, and thickness in the first excavation area (Ex-01, P-1, and P2) displayed variations compared to the crucibles found in Ex-2. In the first excavation area, crucibles were shaped into round bowls with a flat base, and copper fragments were also deposited inside some crucibles fragments. However, crucible lids (or lid fragments) were not found in this area. However, the 
metalworking process using copper and the crucibles are more likely to be an alloying process or a re-production than an extraction process. Juleff (2013) has presented a similar idea regarding the copper products discovered during excavations (1980-84) in the old port city of Mannar. Besides, researchers have pointed out that copper is sourced from the Seruvila copper deposit (in the eastern part of Sri Lanka) as a raw material for the Mannar port city and South Indian copper needs. (Juleff, 2013; Seneviratne, 1995; Srinivasan, 2016). There is no need to challenge that view as no copper deposits have been discovered so far near Mannar or Yodhawewa.

Fig. 7. Fragmented crucibles were collected from the Ex-02 area. The lid, body, and base were presented from inner and outer surfaces.

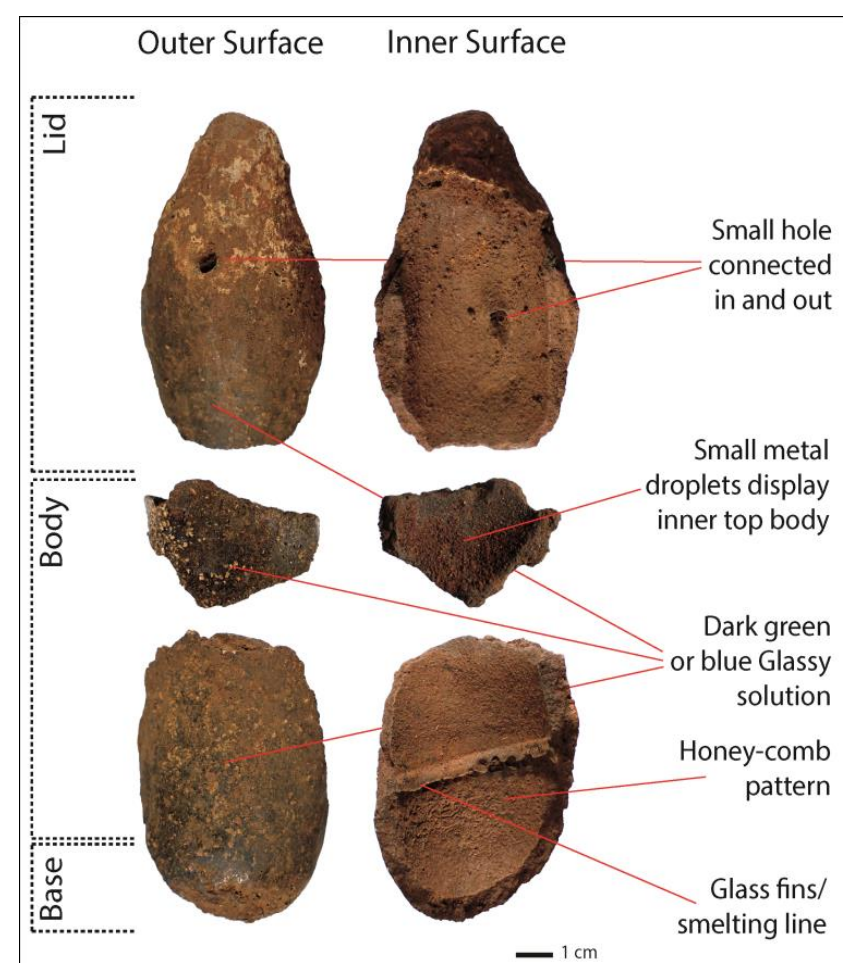

\section{d) Glass produced at the Yodhawewa area?}

Although various researchers have hinted that there may be an indigenous glass industry based on glass artefacts unearthed in various archaeological locations of Sri Lanka, no extensive archaeological study of such products has been conducted. However, in the Ex-02 area of the Yodhawewa site, there were many scattered 
fragments of slags glass (semi-glass fragments or glass-ceramics). These were lighter than metal slag and were mainly blue, green, white, or subtle colour stripes (Fig. 5D-E). Some glass slags are either transparent or translucent (Fig. 5F). Their sizes are in the range of $1.1-1.5 \mathrm{~cm}^{3}$, and a higher quantity of samples $(n=163)$ was recorded from the Ex-02 and the surrounding (These glass slags/semi-gloss fragments/glass-ceramics included in the slags category in Table 1). The addition of silica during the extraction process separates the slag and iron well during the extraction process, creating a glass-ceramic volume in the slag bulk (Tong et al., 2021). The different colours of such glass-ceramic slags can be shown with the chemical reaction with the metal particles during the extraction process. Because some researchers suggest that the metal was used to make coloured glass; hence metal slags can be in the presence of glass manufacturing sites (Ettler et al., 2015; Henderson, 1985). According to Francis (1982), Indian beadmakers made glass beads of specific colours using different amounts of iron, copper, manganese, and antimony mixing with the batch. All three of the above examples show that mixing different metal compositions is inevitably a factor in the colour change of glass. Accordingly, the glass typed slag fragments found in the Yodhawewa site are more likely to be a by-product of the metal extraction, refining (iron or copper), or crucible steel production process.

\section{e) International Relations with Yodhawewa}

The Yodhawewa production site near Mannar, the hub of South Asia on the Silk Road of the sea, cannot be defined as a place where only local needs were met. It was also confirmed that information on international relations was presented by investigating and comparing the morphological dynamics expressed by artefacts. Forty-one artefacts were used to substantiate this fact; 12 Rouletted Ware (RW) fragments, 23 Black and Red ware (BRW) fragments, six Porcelainware fragments, and one coin collected from exploration. Researchers confirm that imported BRW and RW pottery types were widely used in the Asian region, including historic settlements in Sri Lanka, from the $2^{\text {nd }}$ century BC to the $2^{\text {nd }}$ century AD (Magee, 
2010; Schenk, 2001, 2006). One of the identified Changsha porcelain bowl fragments belongs to China's Tang Dynasty period (c. 610-907 AD). Various types of Chinese porcelain have been collected from excavations at the Ancient Mannar port-city, and the excavations 1980-84 have been given special attention to Changsha porcelainware (Carswell, 2013; Linrothe, 2013).

The coin's obverse depicts a lion standing in the middle of a beads circle, and a large flower pot on the reverse, this type of coin belongs to the Pallava dynasty of South India. The Pallava kingdom was established based on the South Indian Kanchipuram in the seventh and eighth centuries AD. In their short-lived kingdom period, the Pallava kings maintained significant political stability in the South Indian region and maintained a good relationship with Sri Lanka (Avari, 2016; Bohingamuwa, 2017; Dirks, 1976). Accordingly, it is not a coincidence that Pallava coins were found in the Yodhawewa research, and these types of coins have been found in Mannar and Anuradhapura in Sri Lanka before (Codrington, 1994).

\section{f) Other Artefacts found from the Yodhawewa research}

In this research paper, metal fragments, glass vessel fragments, beads, minerals, rocks, floral, and faunal factors were pointed out under the same category, and those are $2.56 \%$ of the total artefacts of Yodhawewa research (Fig. 3). Ceramics representing $43.61 \%$ of the total artefacts of this research also have been included in the same category (Fig. 3). Accordingly, this chapter provides a brief overview of those acquisitions and stimulates the need for future research. 

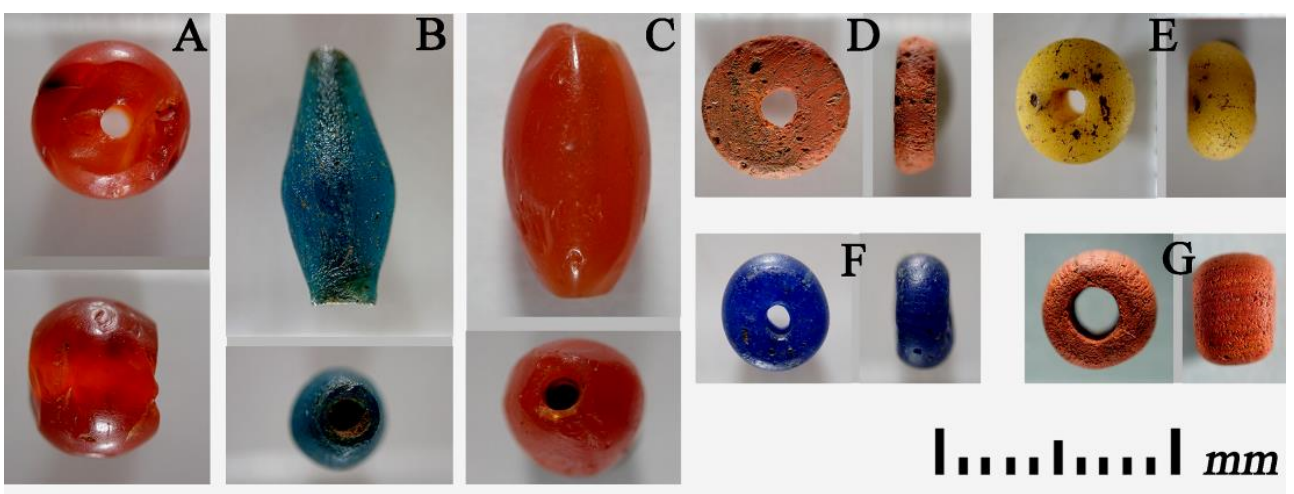

Fig. 8. Yodhawewa Beads, (A) Carnelian/Agate short barrel circular bead (B) Glass long truncated bicone circular bead (C) Carnelian /Agate long truncated convex bicone circular bead (D) Semigloss/Terracotta barrel disc circular bead (E) Glass short barrel circular bead (F) Glass short barrel circular bead (G) Semi-gloss/ Terracotta short barrel circular bead (nomenclature sources; Beck, 2006) (Scale: $10 \mathrm{~mm}$ )

\begin{tabular}{|c|c|c|c|c|}
\hline \multirow{2}{*}{$\begin{array}{c}\text { Pottery and Porcelain Ware } \\
\text { types }\end{array}$} & \multicolumn{3}{|c|}{$\begin{array}{l}\text { The development of pottery and porcelain in Sri } \\
\text { Lanka }\end{array}$} & \multirow{2}{*}{$\begin{array}{l}\text { Yodhawewc } \\
\text { Current } \\
\text { Research }\end{array}$} \\
\hline & Anuradhapura & Thissamaharama & Mannar & \\
\hline Black and Redware & $\checkmark$ & $\checkmark$ & $\checkmark$ & $\checkmark$ \\
\hline Fine Redware & $\checkmark$ & $\checkmark$ & $\checkmark$ & $\checkmark$ \\
\hline Coarse Redware & $\checkmark$ & $\checkmark$ & $\checkmark$ & $\checkmark$ \\
\hline Graphited ware & $\checkmark$ & $\checkmark$ & $\checkmark$ & $\checkmark$ \\
\hline Mica-slipped ware & $\checkmark$ & $\checkmark$ & $\checkmark$ & NI \\
\hline Blackware & $\checkmark$ & $\checkmark$ & $\checkmark$ & $\checkmark$ \\
\hline Fine Grey ware & $\checkmark$ & $\checkmark$ & $\checkmark$ & $\checkmark$ \\
\hline Red Polished ware & $\checkmark$ & $\checkmark$ & $\checkmark$ & $\checkmark$ \\
\hline Red-on-White Painted ware & $\checkmark$ & $\checkmark$ & $\checkmark$ & $\checkmark$ \\
\hline Glazed ware & $\checkmark$ & $\checkmark$ & $\checkmark$ & $\checkmark$ \\
\hline Rouletted ware & $\checkmark$ & $\checkmark$ & $\checkmark$ & $\checkmark$ \\
\hline White Stoneware & $\checkmark$ & $\checkmark$ & $\checkmark$ & $\checkmark$ \\
\hline Islamic ware & $\checkmark$ & $\checkmark$ & $\checkmark$ & $\checkmark$ \\
\hline Turquoise glazed ware & NR & $\checkmark$ & $\checkmark$ & $\checkmark$ \\
\hline Unglazed ware & $\checkmark$ & NR & $\checkmark$ & $\checkmark$ \\
\hline Yue ware & $\checkmark$ & NR & $\checkmark$ & $\checkmark$ \\
\hline
\end{tabular}

Table 3. Comparison of the ware types of foreign and local earthenware (pottery and porcelain) collected from Mannar (Graham, 2013), Anuradhapura (Coningham, 2006; Kuna, 1987), Thissamaharama (Schenk, 2001), and Yodhawewa current research in 2018 (NR: Not Reported, NI: Not Identified) 
Pottery is of great value in the study of archaeology, and it belongs to the common artefacts category in most historic settlements (Shepard, 1985). Six thousand one hundred thirteen $(43.61 \%)$ of pottery pieces and porcelain were collected from the entire research. The first excavation has uncovered the most significant number of pottery fragments $(n=2110)$ here (Table 1). Some imported foreign ceramics were described above, and the ceramic diversity detected by the Yodhawewa site is summarized in Table 3. The dominant type of Plain/Coarse ware, clay disks, and a few types of unidentified earthenware (not related to furnaces) were identified from the site. The ceramics are typologically similar to the other significant sites in Sri Lanka as Mannar (Graham, 2013), Anuradhapura (Coningham, 2006; Kuna, 1987), and Tissamaharama (Schenk, 2001).

One hundred sixty beads of the types as glass beads and coloured glass beads (Fig. 8B, E, F), semi-gloss beads (Fig. 8D, G), and glass-stone beads like Carnelian/Agate (Fig. 8A, C) were collected during the study. The majority were disk beads, 52.2 percentage of all beads, and short beads, standard beads, and long beads were reported $29.9 \%, 8.9 \%$, and $8.9 \%$, respectively. The types of the beads were identical to the beads reported from the other archaeological sites of the Anuradhapura period of Sri Lanka (Beck, 2006; Francis, 2013; HannibalDeraniyagala, 2001). Among the coloured glass beads, a range of blue, yellow, red, green, black, white, and transparent beads have been identified. The beads' material, colour, shape, weight, and technology are identical to each type. Although the Yodhawewa research has collected a considerable number of beads signifying the economic and cultural activities and the relations of the ancient settlements, it is expected to present a detailed review in the future.

Through the exploration, gneiss rock artefacts and quartz pebbles were recorded with a smooth surface with one side or several sides. Some rocks and minerals might have been used as raw materials in metalworking activities or as grinding stones. Since the addition of silica in metal extraction helps to separate slag and iron better (Tong et al., 2021), these grinding stones may have been used to grind sand 
for a better quality result. Other minerals and rocks such as green chert, which is not common in this region, and limestone of different varieties were reported.

A shell and a columella of Turbinella pyrum (Indian chank) were collected from the surface, and they should be transported to the region from the coastal area. T. pyrum played a significant role in the coastal economy of Sri Lanka as food as well as a raw material for ornament production (Ratnayake, 2003; Seneviratne, 1985; Siriwardana, 2014). However, the usefulness of the shells revealed by the Yodhawewa research is uncertain.

\section{Conclusions and Future Directions}

Most of the previous archaeological studies focused on the port-city of Mantai; this study ignored that approach and focused directly on understanding the habitats and industrial settlements of the hinterland of Mantai. However, the results of this research cannot be interpreted outside the socio-economic context of the Mannar port city. The radiocarbon (C14) datings of the present study show the use and functions of the region from $1^{\text {st }}$ to the $8^{\text {th }}$ century AD. Archaeological evidence suggests three significant types of metalwork in the study area: iron extraction, copper metalwork, and crucible steel production. The Yodhawewa iron ore extraction was mainly confirmed by factors in furnaces (including 'tuyere' parts) fragments and slags (including tap lags). However, this research did not provide an opportunity to find a complete iron extraction furnace. Archaeological evidence suggests that copper metalwork was carried out in the Yodhawewa area in the blue, green, and white range of glass slags, slags with small copper particles, and copper fragments found in crucibles.

The unique discovery from the Yodhawewa research was a crucible furnace with a lower half-spherical shape (crucible-shaped) for the first time in Sri Lanka. Several such crucible-shaped furnaces have been reported at the Kodumanal Archaeological research (1986-1996) in Tamil Nadu, and it has been confirmed that they were also used to make crucible steel. It has been pointed out that the 'glass typed slags' found 
in the research area are more likely to be a by-product of the metal extraction, refining (iron or copper), or crucible steel manufacturing process, and not the result of glass production. In addition to Juleff's (2013) statement that Sri Lankan (Sarandibi) high-quality steel, which received tremendous demand in the Arab world, may have been exported from the Mannar port, it can be speculated that Yodhawewa crucible steel may have been among them.

The Indian BRW and RW ceramics and Chinese Changsha porcelain discovered in this research reveal direct or indirect relationships with those countries with the research area. Coins belonging to the Pallava kings of southern India have been found at this place, indicating that cultural ties may have existed with that kingdom as well. In addition, imported RW and BRW (c. $1^{\text {st }}-2^{\text {nd }}$ century AD), Chinese porcelain and South Indian Pallava coins (c. $7^{\text {th }}-8^{\text {th }}$ century AD), and carbon-14 dating from Yodhawewa research (c. $1^{\text {st }}, 5^{\text {th }}$, and $8^{\text {th }}$ century AD) confirms that the site was active at the time. Further research is needed on pottery, beads, minerals, rocks, and faunal remains found in the site. It is expected to provide a comprehensive explanation of the cultural and natural functioning of the premises in future research through extensive geochemical and geo-archaeological studies.

\section{Acknowledgement}

We thank Professor P.B. Mandawala, former Act. Director-General of the Department of Archaeology - Sri Lanka for granting permission for the excavation of Yodhawewa premises, the Chairman and committee members of the Research and Publication Committee of the Rajarata University of Sri Lanka for providing financial assistance (under the grant no. RJT/R\&PC/2018/SSH/R/04) for field studies and also Mr. Thilanka Manoj Siriwardana, Senior Lecturer, Department of Archaeology and Heritage Management, the Rajarata University of Sri Lanka for his contribution on giving valuable suggestions and comments for this manuscript. 


\section{References}

Alwis, K. A. D., \& Panabokke, C. R. (1972). Handbook of the Soils of Sri Lanka (Ceylon). Journal of the Soil Science Society of Ceylon, II, 1-97.

Avari, B. (2016). India: The Ancient Past: A History of the Indian Subcontinent from c. 7000 BCE to CE 1200. Routledge.

Beck, H. C. (2006). Classification and Nomenclature of Beads and Pendants. BEADS Journal of the Society of Bead Researchers, 18, 1-76. https://doi.org/10.1016/j.aodf.2008.02.002

Begley, V., Lukace, J. R., \& Kennedy, K. A. R. (1981). Excavations of Iron Age Burials at Pomparippu, 1970. Ancient Ceylon, 4, 49-141.

Bohingamuwa, W. (2017). Ancient " Mahatittha " (Mantai) in Sri Lanka: A Historical Biography. Journal of the Royal Asiatic Society of Sri Lanka, 62(2), 23-50. https://www.jstor.org/stable/45219028

Carswell, J. (2013). Chinese ceramics. In J. Carswell, S. Deraniyagala, \& A. Graham (Eds.), Matai City by the Sea (pp. 231-238). Linden Soft Verlage e.K.

Carswell, J., Deraniyagala, S. U., \& Graham, A. (Eds.). (2013). Mantai: City by the Sea. Linden Soft Verlag e.K.

Codrington, H. W. (1994). Ceylon Coins and Currency. Asian Educational Services.

Coningham, R. A. E. (2006). Anuradhapura: the British-Sri Lankan excavations at Anuradhapura Salgaha Watta: Volume 2: the artefacts (No. 1508). Archaeopress.

Coomaraswamy, A. K. (1962). Medieval Sinhalese art (2nd ed.). Pantheon Books.

Cooray, P. G., \& Katupotha, J. (1991). Geological Evolution of the coastal zone of Sri Lanka. Symposium on" Causes of Coastal Erosion in Sri Lanka", 5-26.

Deraniyagala, S. U. (1992). The prehistory of Sri Lanka: an ecological perspective. Department of Archaeological Survey, Govt. of Sri Lanka.

Dirks, N. B. (1976). Political Authority and Structural Change in Early South Indian History. Indian Economic \& Social History Review, 13(2), 125-157. https://doi.org/10.1177/001946468101300201 
Eliyahu-Behar, A., Yahalom-Mack, N., Gadot, Y., \& Finkelstein, I. (2013). Iron smelting and smithing in major urban centres in Israel during the Iron Age. Journal of Archaeological Science, 40(12), 4319-4330. https://doi.org/10.1016/j.jas.2013.06.009

Ettler, V., Johan, Z., Zavřel, J., Selmi Wallisová, M., Mihaljevič, M., \& Šebek, O. (2015). Slag remains from the Na Slupi site (Prague, Czech Republic): Evidence for early medieval non-ferrous metal smelting. Journal of Archaeological Science, 53, 72-83. https://doi.org/10.1016/j.jas.2014.10.007

Francis, P. (1982). The Glass Beads of India. Millefiori.

Francis, P. (2013). The Beads. In J. Carswell, S. Deraniyagala, \& A. Graham (Eds.), Mantai: City by the Sea (pp. 349-373). Linden Soft Verlag e.K. https://doi.org/10.2307/j.ctv13pk5kt.18

Georgakopoulou, M. (2014). Metallurgical remains from regional surveys of "non-industrial" landscapes: The case of the kythera island project. Journal of Field Archaeology, 39(1), 6783. https://doi.org/10.1179/0093469013Z.00000000071

Graham, A. (2013). Pottery from the excavation sequence in trenches H and G. In J. Carswell, S. Deraniyagala, \& A. Graham (Eds.), Mantai: City by the Sea (pp. 191-212). Linden Soft Verlag e.K.

Gullapalli, P. (2009). Early metal in South India: Copper and iron in megalithic contexts. Journal of World Prehistory, 22(4), 439-459. https://doi.org/10.1007/s10963-009-9028-0

Hannibal-Deraniyagala, A. (2001). Beads from Tissamaharama - A typology of Sri Lankan glass and semi-precious stone beads. In H. J. Weisshaar, H. Roth, \& W. Wijeyapala (Eds.), Ancient Ruhuna: Sri Lankan-German Archaeological Project in the Southern Province (Vol. 1, Vol. 1, pp. 203-226). Verlag Philipp Von Zabern.

Henderson, J. (1985). The Raw Materials of Early Glass Production. Oxford Journal of Archaeology, 4(3), 267-291. https://doi.org/10.1111/j.1468-0092.1985.tb00248.x

Juleff, G. (1996). Early Iron and Steel in Sri Lanka. Ph.D. Thes., University of London.

Juleff, G. (2013). Metal-Working at Mantai. In J. Carswell, S. U. Deraniyagala, \& A. Graham (Eds.), Matai: City by the Sea (pp. 277-312). Linden Soft Verlage e.K.

Juleff, G. (2015). Crucible steel at Hattota Amune, Sri Lanka, in the first millennium AD: 
archaeology and contextualisation. In S. Srinivasan, S. Ranganathan, \& A. Giumlia-Mair (Eds.), Metals and Civilizations: Proceedings of the Seventh International Conference on the Beginnings of the Use of Metals and Alloys (BUMA VII) (pp. 78-86). National Institute of Advanced Studies.

Karunaratne, P., \& Adikari, G. (1994). Excavations at Aligala Prehistoric Site. In S. Bandaranayake \& M. Mogren (Eds.), Further Studies in the Settlement Archaeology of Sigiriya Dambulla Region (pp. 55-62). PGIAR.

Killick, D. (2014). From Ores to Metals. In R. B \& T. C (Eds.), Archaeometallurgy in Global Perspective. Springer. https://doi.org/https://doi.org/10.1007/978-1-4614-9017-3_2

Kuna, M. (1987). Local Pottery of Anuradhapura: A way to its Classification and Chronology. Památky Archeologické, 78(1), 5-66.

Linrothe, R. (2013). A Changsha Sherd. In J. Carswell, S. Deraniyagala, \& A. Graham (Eds.), Mantai: City by the Sea (pp. 267-269). Linden Soft Verlag e.K.

Magee, P. (2010). Revisiting Indian Rouletted Ware and the impact of Indian Ocean trade in Early Historic south Asia. Antiquity, 84(326), 1043-1054. https://doi.org/10.1017/S0003598X00067065

Parr, J. F., \& Boyd, W. E. (2002). The Probable Industrial Origin of Archaeological Daub at an Iron Age Site in Northeast Thailand. Geoarchaeology - An International Journal, 17(3), 285-303. https://doi.org/10.1002/gea.10013

Pemadasa, M. A. (1984). Grasslands. In H. Dumont (Ed.), Ecology and Biogeography in Sri Lanka (pp. 99-131). Dr. W. Junk Publishers.

Prickett-Fernando, M. (2003). Mantai-Mahatittha: the great port and entrepot in the Indian Ocean trade. In S. Bandaranayake, L. Dewaraja, R. Silva, \& K. D. G. Wimalaratne (Eds.), Sri Lanka and the Silk Road of the Sea (2nd ed., pp. 107-113). Sri Lanka Institute of International Relations.

Ratnayake, H. (2003). The Jetavana Treasure. In S. Bandaranayake, L. Dewaraja, R. Silva, \& K. D. G. Wimalaratne (Eds.), Sri Lanka and the Silk Road of the Sea (pp. 37-52). Sri Lanka Institute of International Relations.

Sasisekaran, B., \& Raghunatha Rao, B. (2001). Iron in Ancient Tamilnadu. In Metallurgy in 
India: A Retrospective (pp. 92-103). India International Publisher.

Schenk, H. (2001). The Development of Pottery at Thissamaharama. In H. J. Weisshaar, H. Roth, \& W. Wijeyapala (Eds.), Ancient Ruhuna: Sri Lankan-German Archaeological Project in the Southern Province (Vol. 1, pp. 59-138). Verlag Philipp Von Zabern.

Schenk, H. (2006). The dating and historical value of Rouletted ware. Zeitschrift Für Archäologie Aussereuropäischer Kulturen 1 (German), 1, 123-152.

Seneviratne, S. (1985). Iron technology in Sri Lanka: A preliminary study of resource use and production techniques during the early iron age. Sri Lanka Journal of the Humanities, XI(1 \& 2), 129-166.

Seneviratne, S. (1995). The Ecology and Archaeology of the Seruwila Copper-Magnetite Deposit, North East Sri Lanka. The Sri Lanka Journal of the Humanities, xxi(1 and 2), 114 145. http://hdl.handle.net/123456789/2449

Shepard, A. O. (1985). Ceramics for the Archaeologist. In The South African Archaeological Bulletin (Vol. 13, Issue 52). CARNEGIE INSTITUTION OF WASHINGTON. https://doi.org/10.2307/3887225

Siriwardana, T. (2014). History of the use of molluscs in Sri Lanka. Biodiversity Secretariat, Ministry of Environment and Renewable energy.

Solangaraarachchi, R. (2011). Ancient iron smelting technology and the settlement pattern in the Kiri oya basin in the dry zone of Sri Lanka [Ph.D. Thes., University of Florida]. https://doi.org/10.16194/j.cnki.31-1059/g4.2011.07.016

Srinivasan, S. (2013). Indian iron and steel, with reference to southern India. The World of Iron, 83-90.

Srinivasan, S. (2016). Tamil Chola Bronzes and Swamimalai Legacy: Metal Sources and Archaeotechnology. JOM, 68(8), 2207-2221. https://doi.org/10.1007/s11837-016-1959-1

Srinivasan, S. (1997). Crucible steel in South India-preliminary investigations on crucibles from some newly identified sites. Materials Research Society Symposium, 462, 111-125.

Srinivasan, S., \& Ranganathan, S. (2004). India's Legendary Wootz Steel. National Institute of Advanced Studies and Indian Institute of Science. 
Thantilage, A., \& Vithanage, I. (2015). Resource Utilization in Sri Lanka Historical Iron Production (J. Weerasinghe (Ed.); No. 4; Occasional Paper). PGIAR.

Tong, Z. B., Sun, J., Wang, J., Tan, Z. J., \& Liu, S. (2021). Iron reduction and diopsidebased glass ceramic preparation based on mineral carbonation of steel slag. Environmental Science and Pollution Research, 28(1), 796-804. https://doi.org/10.1007/s11356-02010358-2

Weisshaar, H. J., Roth, H., \& Wijeyapala, W. (Eds.). (2001). Ancient Ruhuna: Sri LankanGerman Archaeological Project in the Southern Province (Vol. 1). Verlag Philipp Von Zaber.

Weisshaar, H. J., Schenk, H., \& Wijeyapala, W. (2001). Excavations in the Citadel at Akurugoda: The Workmen's Quarter (Tissa 1) and the Court's Garden (Tissa 2). In H. J. Weisshaar, H. Schenk, \& W. Wijeyapala (Eds.), Ancient Ruhuna Sri Lankan-German Archaeological Project in the Southern Province (Vol. 1, pp. 5-39). Verlag Philipp von Zabern. 